\title{
Positive action for HIV in schools in Kenya
}

\author{
Francis Obare \\ Population Council \\ Harriet Birungi \\ Population Council \\ Monica Wanjiru \\ Population Council \\ Sheila Bayley \\ Population Council \\ John Kiunjuri
}

See next page for additional authors

Follow this and additional works at: https://knowledgecommons.popcouncil.org/departments_sbsr-rh

Part of the Demography, Population, and Ecology Commons, Family, Life Course, and Society Commons, Health Policy Commons, Immune System Diseases Commons, International Public Health Commons, Medicine and Health Commons, and the Virus Diseases Commons How does access to this work benefit you? Let us know!

\section{Recommended Citation}

Obare, Francis, Harriet Birungi, Monica Wanjiru, Sheila Bayley, John Kiunjuri, Mary Omondi, Rob Burnet, and Bridget Deacon. 2012. "Positive action for HIV in schools in Kenya," APHIA II OR Project in Kenya Technical Report. Nairobi: Population Council. 


\section{Authors}

Francis Obare, Harriet Birungi, Monica Wanjiru, Sheila Bayley, John Kiunjuri, Mary Omondi, Rob Burnet, and Bridget Deacon 
TECHNICAL

REPORT

Positive Action for HIV in Schools in Kenya

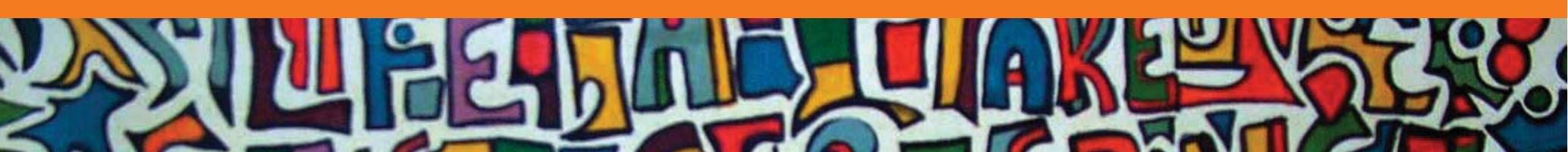
2. 1) 100

J5 50 ,

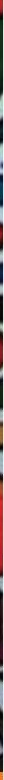

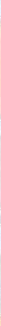




\section{Positive Action for HIV in Schools in Kenya}

APHIA II Operations Research Project, Population Council Francis Obare, Harriet Birungi, Monica Wanjiru, Sheila Bayley

Ministry of Education

John Kiunjuri, Mary Omondi

Well Told Story

Rob Burnet, Bridget Deacon

National AIDS and STI Control Programme

Christine Awuor

March 2012 
The Population Council, Inc. One Dag Hammarskjold Plaza, New York, New York, 10017.

(C) 2012 The Population Council, Inc.

The Population Council confronts critical health and development issues-from stopping the spread of HIV to improving reproductive health and ensuring that young people lead full and productive lives. Through biomedical, social science, and public health research in 50 countries, we work with our partners to deliver solutions that lead to more effective policies, programs, and technologies that improve lives around the world. Established in 1952 and headquartered in New York, the Council is a nongovernmental, nonprofit organization governed by an international board of trustees.

\section{www.popcouncil.org}

This publication has been made possible with the generous support of the American people through USAID/Kenya, under the APHIA II

Operations Research Project, a cooperative agreement No. 623-A-00-0900001-00 between the Kenya Mission and the Population Council. The opinions expressed herein are those of the authors and do not necessarily reflect the views of USAID.

Cover painting: (C) 2009, Eirik Jarl Trondsen

Eirik Jarl Trondsen was born in Oslo, Norway, studied in Uganda, and worked with art in the Kibera slum of Nairobi and currently lives in Kenya. Contact: ejtconsult@gmail.com. The painting on the cover page signifies the colorful and energetic world. It represents a transition between form and formless inspirations, and includes shapes and words of life: integrity, responsibility, hope, and justice for all.

Suggested Citation: Francis Obare, Harriet Birungi, Monica Wanjiru, Sheila Baiyley, John Kiunjuri, Mary Omondi, Rob Burnet, Bridget Deacon. 2012. Positive Action for HIV in Schools in Kenya. APHIA II OR Project in Kenya. Population Council: Nairobi, Kenya.

Any part of this publication may be photocopied without permission from the publisher provided that copies are distributed without charge and that full source citation is provided. The Population Council would appreciate receiving a copy of any materials in which the text is used. 


\section{Contents}

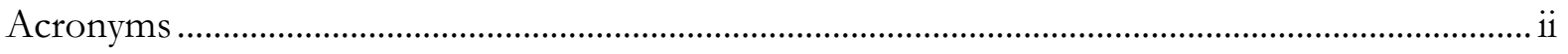

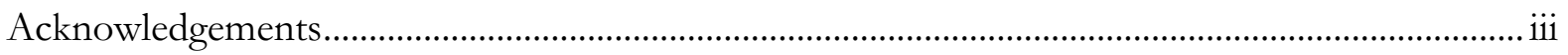

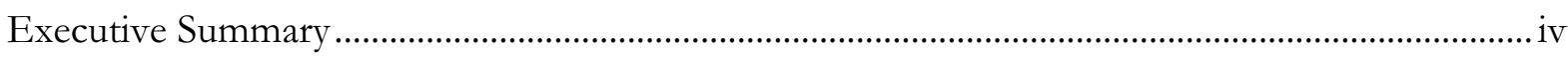

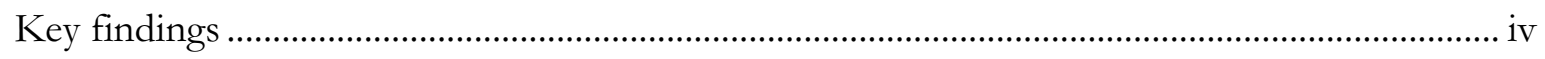

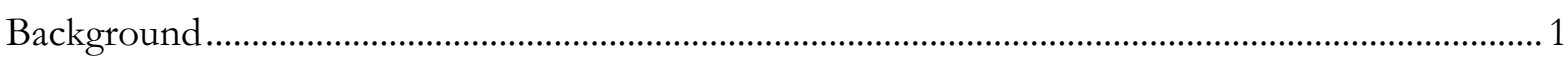

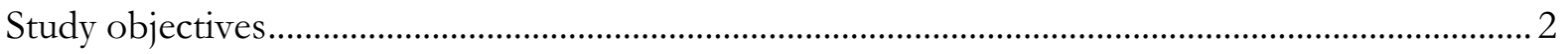

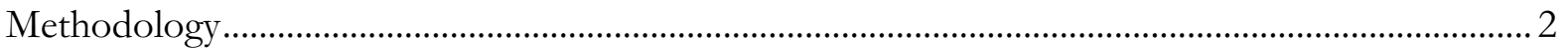

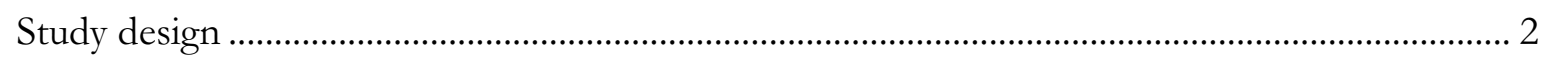

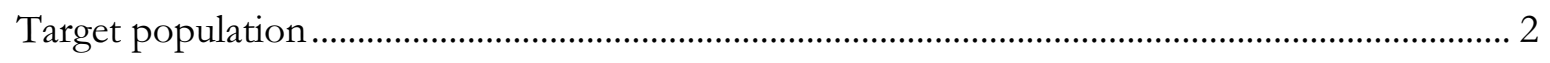

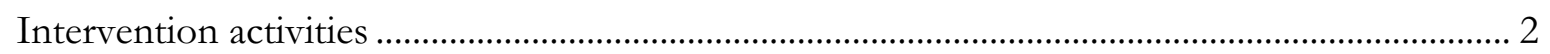

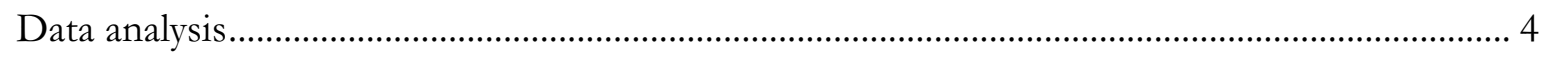

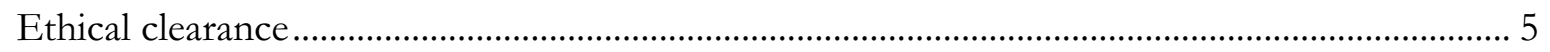

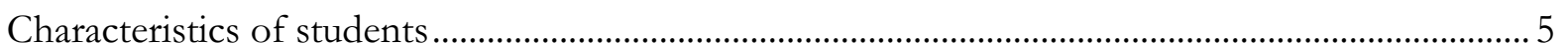

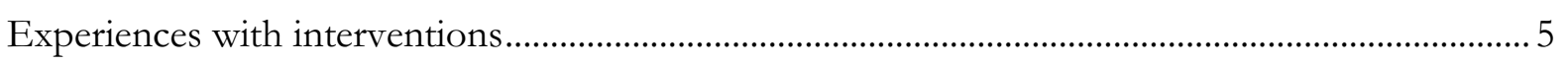

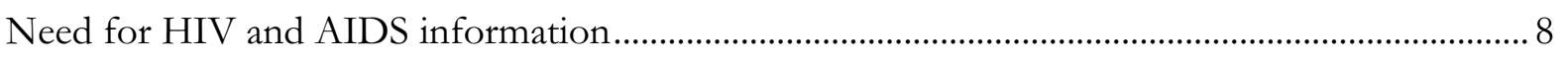

Need for other sexual and reproductive health information............................................................. 9

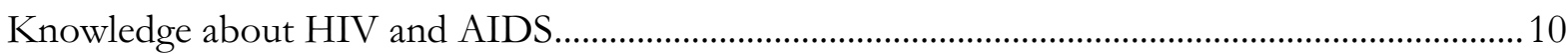

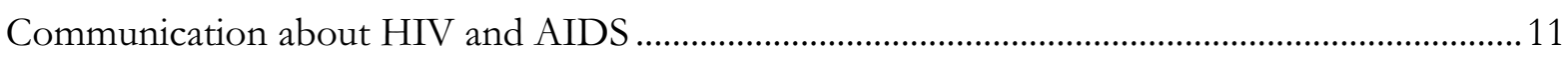

Attitudes towards people living with HIV ………….......................................................................14

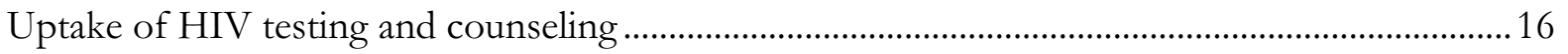

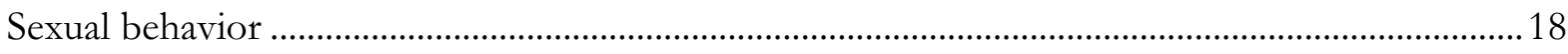

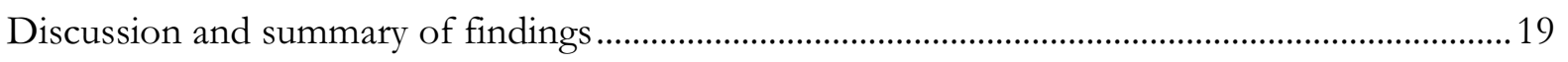

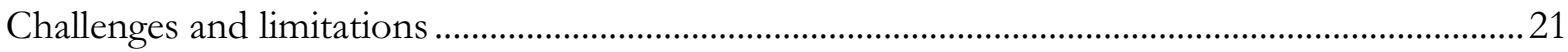

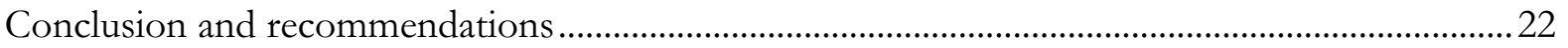

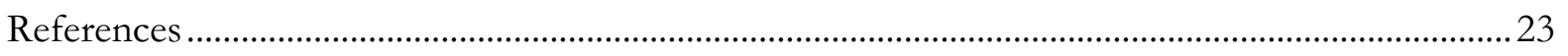




\section{Acronyms}

AIDS

APHIA

ARV

ERC

GNP+

HIV

ILO

IRB

KEMRI

KNBS

MOPHS

NASCOP

NCST

OR

PHDP

PTA

SNEP

SRH

STI

UNAIDS

UNESCO

USAID

VCT
Acquired Immunodeficiency Syndrome

AIDS, Population and Health Integrated Assistance

Antiretroviral Drugs

Ethics Review Committee

Global Networking of People Living with HIV/AIDS

Human Immunodeficiency Virus

International Labour Organization

Institutional Review Board

Kenya Medical Research Institute

Kenya National Bureau of Statistics

Ministry of Public Health and Sanitation

National AIDS and STI Control Programme

Kenya National Council of Science and Technology

Operations Research

Positive Health, Dignity and Prevention

Parents-Teachers Association

Special Needs Education Policy

Sexual and Reproductive Health

Sexually Transmitted Infection

Joint United Nations Programme on HIV/AIDS

United Nations Educational, Scientific and Cultural Organization

United States Agency for International Development

Voluntary Counseling and Testing 


\section{Acknowledgements}

This report is based on a study that was funded by the United States Agency for International Development (USAID)/Kenya Mission through cooperative agreement 623-A-00-09-00001-00 between the Mission and the Population Council. The study was implemented by the APHIA II Operations Research Project in collaboration with the AIDS Control Unit in the Ministry of Education, Well Told Story, and the National AIDS/STI Control Programme (NASCOP).

The project received logistical guidance and support from the Director of Policy and Planning in the Ministry of Education: Mr. Kiragu Magochi; the District Quality Assurance and Standards Officers: Hellen Bornett, Timothy Ndigutu, Edna Ambassa, Moses Muita, Lydia Muchemi, and Cecilia Kihembe; the Principals of the participating schools: Mr. Cleophas Tirop, Mr. Stephen Njoroge, Mrs. Zuhura Rajab, Mrs. Margret Njaggah, Mrs. Conslata Kimuya, Mr. Maurice Okumo, Mrs. Emma Odongo, and Mrs. Jael Muriithi; and the Guidance and Counseling teachers: Mrs. Anna Mutua, Ms. Damaris, Ingrid Moragwa, Roselyn Watitwa, Mrs. Kimani, Mrs. Kiragu, Mrs. Mukui, Ms. Ruth Wanjiku, Mrs. Rose Mutonga, Mrs. Vivian Obonyo, Mrs. Magdaline Obonyo, and Theresia Mumbi. We further acknowledge the invaluable cooperation received from students and teachers in general.

The communications materials were developed by Well Told Story. Bridget Deacon created and developed the content with the assistance of Charles Ouda while Salim Busuru was responsible for designing the communications materials. Anne-Rose Waceke provided administrative support including the distribution of the materials to schools and collating feedback from students and teachers. Kevin Waire and Charles Ouda conducted the edutainment activities. Margaret Nzina and Peris Gichanga, the District AIDS and STI Coordinators under the Ministry of Public Health and Sanitation, conducted the health talks. The training of school-based caregivers on HIV care and support was undertaken by Eunice Okoth, a consultant and expert on sexual and reproductive health including HIV and AIDS.

The successful completion of the project was also made possible by a team of research assistants including Christabell Hoka, Brian Solomon, and Daisy Sabwa. The data were entered by Caroline Apiyo, Florian Lugaliki, David Ochieng', Irean Wangechi, Boniface Odindo, Khadija Ali, Sarah Omai, and Grace Mwema.

Winnie Osulah of the Population Council provided invaluable administrative support for the project while Erick Oweya and Arnold Assava oversaw the designing of the databases and data entry.

The Institutional Review Board (IRB) of the Population Council, the Ethics Review Committee of the Kenya Medical Research Institute (KEMRI), and the National Council for Science and Technology (NCST) granted ethical and research clearance for the study. 


\section{Executive Summary}

Although many sub-Saharan African countries that are affected by HIV and AIDS have developed education sector policies in response to the epidemic, there are still challenges in effectively addressing the issue in schools. These challenges include lack of appropriate leadership and coordination at the school level, limited training and skills update on HIV and AIDS among school-based caregivers (teachers, school nurses and matrons), absence of appropriate guidelines in some settings, and lack of coordination between the education, health and other sectors. For example, in Kenya, although national guidelines exist for providing HIV services to various segments of the population, the education sector policy is silent on how the services can be provided to in-school youth.

The objective of this study was to test the feasibility of using comic books, role models and edutainment to communicate HIV and AIDS messages to in-school young people with a view to improving their knowledge about the epidemic, enhancing communication about it, and promoting positive attitudes and behavior among them. The study was conducted as a pilot and used a quasi-experimental pre- and post-intervention design without a comparison group. It was implemented between 2010 and 2011 in eight secondary schools in Nairobi, Kenya, by the APHIA II Operations Research (OR) Project in collaboration with the AIDS Control Unit in the Ministry of Education, Well Told Story, and the National AIDS/STI Control Programme (NASCOP).

\section{Key findings}

Key findings from the study include:

- There is need for HIV and AIDS and other sexual and reproductive health information among students.

- Using youth-friendly channels to communicate HIV and AIDS messages is feasible and acceptable to students.

- There was increased knowledge of modes of HIV transmission and of where to get tested for HIV among students exposed to the interventions.

- There was increased communication about HIV and AIDS among students exposed to the interventions.

- There were positive changes in attitudes towards people living with HIV among students exposed to the interventions.

- There was reduced fear of getting tested for HIV among students exposed to the interventions.

- There were positive changes in the sexual behavior of students exposed to the interventions.

The study showed that:

- in-school youth need accurate information not only on HIV and AIDS but other SRH issues as well;

- using comic books, role models and edutainment to communicate HIV and AIDS messages to in-school youth is acceptable to members of the school community; and

- the use of such channels leads to improved knowledge of SRH issues, enhanced communication about SRH, and positive changes in attitudes and behavior of students. 
The major recommendations from the study are that:

- there is need to constantly provide HIV and AIDS and other SRH information to in-school youth using age-appropriate channels; and

- all education stakeholders (education managers, school principals, teachers, parents/ guardians, and students) need to be involved in the conceptualization and design of such channels to ensure that they are acceptable and feasible within the school setting. 


\section{Background}

The rapid roll-out of antiretroviral (ARV) treatment in parts of sub-Saharan Africa is making it possible for an increasing population of young people (10-19 years) who were either perinatally or sexually infected with HIV to survive longer, enjoy a better quality of life, and, subsequently, to realize their schooling prospects (Birungi et al. 2008; Obare et al. 2009). Yet, education sector responses to HIV and AIDS in the region have predominantly focused on improving students' knowledge about the diseases and developing their skills to protect against infection (ILO and UNESCO 2006; Ward and Mendelsohn 2009). Approaches that address the needs-and acknowledge the rights and dignities_ - of young people living with HIV are generally non-existent because of the false assumption that, aside from children infected perinatally, school-going adolescents constitute a largely HIV-free generation.

However, evidence from the Demographic and Health Surveys shows that young people in the region initiate sexual activity early. In Kenya, for example, the youngest age at first sex is eight years with 39\% of adolescents aged 15-19 years having had sex (Kenya National Bureau of Statistics [KNBS] and ICF Macro 2010). Among these, only 26\% and 22\% reported using a condom at first and last sex respectively. A sizeable number of in-school adolescents may therefore have been exposed to the risk of HIV, yet only a small fraction have been tested for HIV and know their status. For example, about one-third (32\%) of sexually active female adolescents aged 15-19 years were tested for HIV in the 12 months preceding the survey and obtained their test results (KNBS and ICF Macro 2010). Among sexually active male adolescents of similar age group, the figure is much lower $(20 \%)$.

Governments in Africa are beginning to recognize that school-going, HIV-positive young people present a new challenge to the education sector and have developed Education Sector Policies on HIV and AIDS in response (Kelly 2003). These policies have predominantly evolved around a legal framework that recognizes and upholds the rights of all people with a special focus on marginalized and vulnerable groups and those with special needs. They also recognize the need for universal access to HIV and AIDS information, access to treatment and care, protection from discrimination and stigma, and care for orphans and vulnerable children (Ministry of Education and Sports-Uganda 2006; Ministry of Education-Kenya 2004). Yet, rarely have these policies been operationalized to address the special needs of students living with HIV, a problem compounded by the fact that their needs are largely unknown, and that many in-school young people still do not know their status.

In Kenya, the Ministry of Education launched the National Special Needs Education Policy (SNEP) in 2010 (Daily Nation 2010). Whereas SNEP was expanded to include learners with various special needs, it was still silent on the needs of those who are living with HIV. Moreover, although the national guidelines for HIV testing and counseling in Kenya emphasize the need for providing youth-friendly services to adolescents and young adults so long as appropriate consent is obtained (NASCOP 2008), the Ministry of Education policy is silent on the procedures for providing the services to in-school young people (Ministry of Education-Kenya 2004). This project therefore sought to inspire change in the way members of the school community engage with HIV-related issues by generating evidence for enhancing communication about HIV among them, addressing stigma and discrimination in schools, and creating demand for early diagnosis of HIV, counseling, care and support services in order to contribute to positive health, dignity and prevention (PHDP) among young people. ${ }^{1}$

\footnotetext{
${ }^{1}$ Positive health, dignity and prevention (PHDP) framework is a human rights approach based on legal protections and a policy environment free of stigma and discrimination for people living with HIV. It includes a supportive legal and policy environment; focus on holistic health promotion, not only on transmission prevention; tailoring to setting, key populations, and to the individual; and involvement of people living with HIV in designing programs (GNP+ and UNAIDS 2009).
} 
Identifying appropriate interventions to provide information, testing, counseling and support services to young people in schools who are infected with and affected by HIV is a pressing priority for the Ministries of Education in high-prevalence countries including Kenya (UNESCO 2006; Ward and Mendelsohn 2009). Effective education sector interventions will be particularly crucial to ensure that adolescents living with HIV are supported through the existing education system to fully realize their potential to learn and thrive. The project therefore reinforced two areas emphasized by the 2004 Ministry of Education Policy on HIV and AIDS, namely: (1) the provision of accurate, relevant and understandable HIV and AIDS information to all learners, parents, care-givers and education sector employees; and (2) the right to access holistic care, treatment and support for all infected and affected learners, educators, and other personnel.

\section{Study objectives}

To test the feasibility of using youth-friendly communication channels to:

1) increase awareness and enhance communication about HIV and AIDS among students as well as between students and their teachers and parents/guardians;

2) positively change students' attitudes towards people living with HIV by addressing stigma and discrimination and their consequences; and,

3) generate demand for early diagnosis and counseling for HIV among students in order to promote positive health, dignity and prevention.

\section{Methodology}

\section{Study design}

The study was conducted as a pilot and used a quasi-experimental pre- and post-intervention design without a comparison group. It was implemented between 2010 and 2011 by APHIA II Operations Research (OR) Project in collaboration with the AIDS Control Unit in the Ministry of Education, Well Told Story, and the National AIDS/STI Control Programme (NASCOP).

\section{Target population}

Eight secondary schools in Nairobi, Kenya were selected to participate in the study. The Ministry of Education identified the schools based on whether they were national or provincial level, single sex or mixed, day or boarding, made up of students from high, medium or low-income settings, and located in western, eastern, southern, northern or central parts of the city. The project directly targeted in-school adolescent boys and girls aged 12-19 years (hence the focus on secondary schools, given that most young people within this age range are at this level of schooling), their teachers as well as school nurses and matrons. It also aimed at indirectly reaching the parents/guardians of students enrolled in the participating schools.

Prior to implementation, a series of consultative meetings were held with provincial and districtlevel education managers in Nairobi, principals of the participating schools, and representatives from non-governmental organizations and bilateral donors with interests in the education sector. The purpose was to discuss the challenges that HIV poses to the education sector in Kenya, brief the participants about the project, and obtain their views.

\section{Intervention activities}

The interventions were implemented over a five-month period during the school year and involved the use of youth-friendly communication channels including:

1) colorful comic books, guides and posters;

2) use of role models; and

3) educative performances (edutainment). 
The intervention activities were preceded by formative research involving group discussions and written essays with students, teachers and parents/guardians from six of the eight schools. The purpose of the formative research was to obtain information to guide the design of the interventions. The groups were selected based on the nature and composition of each school. For instance, discussions with groups of parents were only possible in day schools where they could be easily mobilized. Each group comprised about six participants and had a facilitator and a note-taker. The discussions were not tape-recorded.

Comic books, guides and posters: These included three issues of colorful comic books for students and accompanying parents' and teachers' guides as well as colorful posters for classrooms and staff rooms. The materials were developed and distributed to the participating schools by Well Told Story between February and April 2011. Copies of the materials were first shared by the Ministry of Education for approval before being pre-tested among groups of students and teachers from schools not participating in the project. Each of the three issues of the comic books and guides focused on a specific theme on HIV/AIDS. The first issue focused on communicating about HIV and AIDS, the second addressed the need for testing and counseling for HIV, while the third dealt with stigma and discrimination and their consequences on those who are exposed to them.

The comic books were distributed to all students in the participating schools who were present on the day the materials were delivered to the schools. The comic books were titled Kuwa Shujaa ('be a hero') as a way of inspiring students to be champions of positive behavior and were based on role model characters and familiar scenarios and locations. The purpose was to illustrate best and worst practices, combine drama with factual information, raise important issues and questions, and foster debate among students and teachers about HIV and AIDS. The comic books also had some interactive activities for students to undertake such as raising questions or concerns and expressing these through word and art. Students were, for instance, challenged to write down their thoughts about HIV and AIDS, turn these into eye-catching posters that would convey the message to the people around them, and share their posters with their colleagues. A total of 14,700 comic books, 6,900 teachers' guides, and 4,000 parents' guides were distributed to the schools.

Drop boxes were also distributed to the participating schools for students to drop in any questions, concerns or comments they had regarding the interventions and HIV and AIDS. During the months of June and July 2011, experts on sexual and reproductive health (SRH) and HIV and AIDS from the Ministry of Public Health and Sanitation (MOPHS) visited six of the eight schools to respond to the questions and concerns that the students had placed in the drop boxes.

The parents' and teachers' guides were designed to assist them in talking about HIV and AIDS with their children/students. Similar to the comic books, the teachers' guides were distributed to all teachers who were present on the day the materials were delivered to the schools and extra copies left for those who were not present. The guides for parents/guardians were distributed by teachers during school open days, annual general meetings, and parents-teachers association (PTA) meetings. The posters, on the other hand, had key messages on HIV and AIDS and appropriate slogans derived from the comic book stories, and were distributed in the participating schools together with the comic books and guides.

Use of role models and edutainment: Two role models were used in the project. One was a local musician who is famous with the youth while the other was an actor who starred in some of the most popular locally produced plays. The project obtained consent from the musician for his image to be used in the comic books. Besides, in each of the eight schools, the launch of the first series of the comic books and guides was accompanied by educative performance (edutainment activities) by the two role models. The performances were meant to convey the key messages in the comic books and on HIV and AIDS under the slogan: know your status, plan your future. The health talks that were 
conducted by officials from MOPHS were also accompanied by educative performance by the local musician. Thus, a total of 13 edutainment activities were undertaken during the intervention period.

Training school-based caregivers: Besides the interventions that directly targeted students and teachers, school-based caregivers (school nurses, matrons and guidance and counseling teachers) from the participating schools were trained on HIV care and support. This was a four-day training conducted by an expert on SRH/HIV and AIDS in April 2010. Its purpose was to equip schoolbased caregivers with skills to effectively engage with students in matters related to HIV and AIDS including appropriately responding to the special needs of students living with HIV.

\section{Data analysis}

Data collection among students was undertaken at two time points-before and after the implementation of the interventions. This involved structured self-administered questionnaires to assess their attitudes and practices regarding information on HIV/AIDS, testing, counseling, stigma and discrimination. Baseline data collection took place in January 2011. Only students from Forms Two to Four participated in the interviews because those entering Form One had not reported to the schools. However, by the start of the interventions in February 2011, Form One students had already joined the schools. They were therefore exposed to the interventions and participated in the endline interviews which were conducted in September 2011. At both baseline and endline, all students who were present on the day scheduled for interviews and for whom parental/ guardian consent and individual assent had been obtained were eligible to complete the questionnaires.

The questionnaires were anonymously administered as a class exercise lasting about 30 minutes. Students were instructed not to write any identifying information such as name or registration number on the questionnaires. Besides ensuring confidentiality and privacy, it was hoped that this would make them respond honestly to the questions. Research assistants distributed the questionnaires, explained the purpose of the study, and remained in the room during the period to answer any procedural or substantive questions the students had. The exercise was scheduled in collaboration with the participating schools at convenient times to avoid interfering with the normal school lessons, for example, in the evening at the end of the lessons or during weekends.

The impact of the interventions is assessed through quantitative data from the self-administered interviews as well as qualitative information based on feedback obtained from students through the drop boxes. The quantitative data were entered in EPIDATA and analyzed using STATA. Analysis involves two sets of comparisons: (1) baseline and endline indicators among students from classes that participated in both interviews (those in Forms Two to Four); and (2) indicators at endline among students from all classes (Forms One to Four) who received and read the communications materials on the one hand and on the other, those who either did not receive the comic books or received but did not read them. The results are presented in the form of frequencies and percentages. Chi-square tests and significance tests of proportions are conducted to determine if the observed differences between groups are statistically significant. The qualitative information obtained from students through the drop boxes was, on the other hand, typed in Word and analyzed for content. Excerpts from the data are provided to support some of the key insights from the study.

The interventions are considered to have had an impact if significantly higher proportions of students reported improved knowledge of HIV and AIDS, increased communication with other people about the epidemic, positive attitudes towards people living with HIV, and increased acceptance of testing and counseling: (1) at endline than at baseline; or (2) among those who read the communications materials than among those who did not obtain or read the materials. This should further be supported by the feedback obtained from students through the drop boxes. The rationale for using the two sets of criteria to determine impact is that the first might be affected by 
the number of students who were actually exposed to the interventions given that the materials were distributed to those who were present on the day the materials were delivered to the schools.

\section{Ethical clearance}

The Ethics Review Committee of the Kenya Medical Research Institute (KEMRI), the Population Council Institutional Review Board, and the National Council for Science and Technology (NCST) granted ethical and research clearance for the study.

\section{Characteristics of students}

A total of 3,408 and 2,914 students from seven of the eight schools completed the questionnaires at baseline and endline respectively. Of those who completed the interviews at endline, 63\% were in Forms Two to Four. Whereas more male than female students completed the interviews at baseline, this was reversed at endline (Table 1). However, at both baseline and endline, the majority of the participants were aged between $15-17$ years $(72 \%$ at baseline and $67 \%$ at endline). Differences in the proportions of students that completed the questionnaires by type of school mirror differences by sex of the respondent. In addition, most of the students lived with biological parents at both baseline and endline (87\% at baseline and $86 \%$ at endline; Table 1).

\begin{tabular}{|c|c|c|c|}
\hline \multirow[b]{2}{*}{ Characteristics } & \multirow[b]{2}{*}{$\begin{array}{l}\text { Baseline (\%) } \\
(\mathrm{N}=3,408)\end{array}$} & \multicolumn{2}{|l|}{ Endline (\%) } \\
\hline & & $\begin{array}{l}\text { Forms } 2 \text { to } 4 \\
(\mathrm{~N}=1,811)\end{array}$ & $\begin{array}{l}\text { All students } \\
(\mathrm{N}=2,914)\end{array}$ \\
\hline Sex of respondent & $p<0.01$ & & \\
\hline Male & 52.1 & 47.1 & 46.4 \\
\hline Female & 47.6 & 53.0 & 53.6 \\
\hline Missing & 0.3 & 0.0 & 0.0 \\
\hline Age group (years) & $p<0.01$ & & \\
\hline$<15$ & 6.8 & 1.7 & 15.8 \\
\hline $15-17$ & 71.6 & 72.6 & 66.6 \\
\hline $18-19$ & 14.2 & 15.6 & 10.2 \\
\hline 20 and above & 2.3 & 3.8 & 2.5 \\
\hline Don't know & 2.7 & 3.7 & 2.9 \\
\hline Missing & 2.4 & 2.7 & 2.0 \\
\hline Type of school & $p<0.01$ & & \\
\hline Boy's boarding & 43.0 & 36.8 & 38.4 \\
\hline Girl's boarding & 40.9 & 47.3 & 47.9 \\
\hline Mixed day & 16.1 & 15.9 & 13.7 \\
\hline Level of schooling & $p<0.01$ & & \\
\hline Form one & $n / a$ & $n / a$ & 37.9 \\
\hline Form two & 32.9 & 40.5 & 25.2 \\
\hline Form three & 34.6 & 45.2 & 28.1 \\
\hline Form four & 32.1 & 13.8 & 8.5 \\
\hline Missing & 0.4 & 0.6 & 0.4 \\
\hline Living arrangements & $p<0.05$ & & \\
\hline Biological parents & 86.5 & 85.3 & 85.9 \\
\hline Relative & 8.3 & 8.0 & 8.6 \\
\hline Alone & 1.9 & 3.3 & 2.3 \\
\hline Friends/other & 2.1 & 2.5 & 2.3 \\
\hline Missing & 1.3 & 1.0 & 0.8 \\
\hline \multicolumn{4}{|c|}{$\begin{array}{l}\text { Notes: } n / a=\text { not applicable for purposes of comparison because Form One students } \\
\text { did not participate in baseline interviews; Percentages may not sum to } 100 \text { due to } \\
\text { rounding; } p \text {-values are from Chi-square tests of differences between baseline and } \\
\text { endline characteristics of students in Forms } 2 \text { to } 4 \text {. }\end{array}$} \\
\hline
\end{tabular}

\section{Experiences with interventions}

Formative research showed that current approaches of conveying HIV and AIDS messages appear repetitive, boring and lack in-depth information for many young people. Most students preferred more relevant, interactive, appealing and realistic approaches of conveying the messages, which could be accomplished through the use of role models, celebrities, guidance and counseling teachers, and school nurses. This view was also held by their teachers as exemplified by the following quote: 
The presentation of the material is important, and how will this material be disseminated. The information packaging must be enjoyable. It must have a good atmosphere... Who will be doing the presentations... they need someone they can relate to, a youth like them (Teacher).

Feedback from students and teachers therefore showed that the intervention activities were well received. The edutainment slogan of know your status, plan your future resonated well with students. This was evident when students responded positively to the presentations and the performances by joining in chanting the slogan and asking questions about HIV and AIDS. Some teachers also reported that they overheard students re-chanting the messages. In addition, students and teachers reported that the intervention activities were relevant and realistic as shown by the following quotes:

Thank you for the comic books. They are so entertaining and interesting...We request you continue sending the books to our school and please make the stories longer (student).

Kuwa Shujaa is a true work of art, encouragement and inspiration. I am happy that you guys have taken the initiative to reach out to us, the youth...Please include a poem corner. I love reading and writing them (student).

It [teacher's guide] is realistic and easy to use for teaching (teacher).

Thanks for the good work you are doing in our secondary schools, keep encouraging the teachers and students on bealth and life skills, you complement our work as school administrators (school principal).

Students and teachers further reported using the materials for various purposes. For example, some teachers reported using the materials to initiate discussions during student club meetings, peer education and counseling sessions and to make the discussions lively. Some students used the interactive sections of the comic books to express their ideas about HIV and AIDS, draw posters based on these ideas, and pin the posters on the notice boards in their classrooms. Other students expressed their talent in art by drawing some of the characters in the comic books.

Among students who participated in the endline interviews, $84 \%$ obtained at least one issue of the comic books (Table 2). A significantly higher proportion of female compared to male students obtained the comic books. Of those who obtained the comic books, 95\% read them. Consistent with qualitative feedback from students, $97 \%$ of the students who read the comic books liked at least one aspect of the materials. The most liked feature of the comic books was the educative content of the messages, followed by responses to some of the questions that students had earlier posed, and the entertaining nature of the cartoons, with no significant difference between male and female students (Table 2). Similarly, some of the features that the students did not like and which are also highlighted in the qualitative excerpts above were that the stories were too short, some questions were not responded to, and the activities were limited in number. 


\begin{tabular}{|c|c|c|c|}
\hline Experience with comic books & $\begin{array}{r}\text { Male students } \\
(\%)\end{array}$ & $\begin{array}{r}\text { Female students } \\
(\%)\end{array}$ & $\begin{array}{r}\text { All students } \\
(\%)\end{array}$ \\
\hline Obtained comic booksa & $(\mathrm{N}=1,353)$ & $(\mathrm{N}=1,561)$ & $(\mathrm{N}=2,914)$ \\
\hline Yes & 81.2 & $86.0^{* *}$ & 83.8 \\
\hline No & 9.5 & $7.4^{*}$ & 8.4 \\
\hline Missing & 9.2 & $6.6^{* *}$ & 7.8 \\
\hline Read comic books ${ }^{a}$ & $(\mathrm{~N}=1,099)$ & $(\mathrm{N}=1,343)$ & $(\mathrm{N}=2,442)$ \\
\hline Yes & 94.3 & $96.0^{*}$ & 95.2 \\
\hline No & 2.2 & 1.3 & 1.7 \\
\hline Missing & 3.6 & 2.8 & 3.1 \\
\hline Liked the comic books & $(\mathrm{N}=1,036)$ & $(\mathrm{N}=1,289)$ & $(\mathrm{N}=2,325)$ \\
\hline Yes & 96.4 & 96.7 & 96.6 \\
\hline No & 3.6 & 3.3 & 3.4 \\
\hline Features liked about comic books ${ }^{b}$ & $(\mathrm{~N}=1,036)$ & $(\mathrm{N}=1,289)$ & $(\mathrm{N}=2,325)$ \\
\hline Stories/messages were educative & 87.2 & 87.0 & 87.1 \\
\hline Responses to questions were informative & 51.4 & 54.5 & 53.1 \\
\hline Characters/cartoons were entertaining & 44.4 & 45.9 & 45.3 \\
\hline Books were colorful/appealing & 34.0 & 30.6 & 32.1 \\
\hline Activities/workbooks were fun & 30.6 & 31.9 & 31.3 \\
\hline Other & 5.8 & 6.3 & 6.1 \\
\hline Features not liked about comic books ${ }^{b}$ & $(\mathrm{~N}=1,036)$ & $(\mathrm{N}=1,289)$ & $(\mathrm{N}=2,325)$ \\
\hline Stories/messages were too short & 32.4 & $39.3^{* *}$ & 36.2 \\
\hline Some questions were not answered & 18.5 & 19.4 & 19.0 \\
\hline Activities/workbooks were not enough & 17.0 & 17.4 & 17.2 \\
\hline Color of the comic books were dull & 6.7 & 8.8 & 7.8 \\
\hline Stories/messages were boring & 6.4 & 5.7 & 6.0 \\
\hline Characters/cartoons were not appealing & 7.9 & $3.3^{* *}$ & 5.3 \\
\hline Other & 5.7 & 4.7 & 5.2 \\
\hline \multicolumn{4}{|c|}{$\begin{array}{l}\text { Notes: aPercentages may not sum to } 100 \text { due to rounding; bQuestions allowed for multiple responses; } \\
\text { Differences between male and female students are significant at: }{ }^{*} p<0.05 ;{ }^{* *} p<0.01 \text {. }\end{array}$} \\
\hline
\end{tabular}

Table 3 presents the distribution of students who participated in endline interviews by whether they read the comic books according to background characteristics. There were significant variations in the distribution of students who read the comic books and those who did not obtain or read the materials. In particular, students aged 15-17 years, attending girls' boarding institutions, in Form One, or living with biological parents constituted the highest proportions of those who read the comic books. These proportions were significantly higher than those of students with similar characteristics who did not obtain or read the comic books. In contrast, the proportions of students that were older (aged 18 years and above), in mixed day schools, in higher classes (Forms Two to Four), or living with other persons (relatives, alone or friends) that did not obtain or read the comic books were significantly higher than the proportions of those with similar characteristics who read the comic books (Table 3). 


\begin{tabular}{|c|c|c|}
\hline & $\begin{array}{r}\text { Read comic books (\%) } \\
(\mathrm{N}=2,325)\end{array}$ & $\begin{array}{l}\text { Did not obtain/read comic books (\%) } \\
\qquad(\mathrm{N}=589)\end{array}$ \\
\hline \multicolumn{3}{|l|}{ Age group (years) } \\
\hline$<15$ & 17.9 & $7.8^{* *}$ \\
\hline $15-17$ & 67.5 & $63.2^{*}$ \\
\hline $18-19$ & 9.0 & $14.9^{* *}$ \\
\hline 20 and above & 1.9 & $4.9^{* *}$ \\
\hline Don't know & 1.8 & $7.1^{* *}$ \\
\hline Missing & 2.0 & 2.0 \\
\hline \multicolumn{3}{|l|}{ Type of school } \\
\hline Boy's boarding & 39.1 & 35.5 \\
\hline Girl's boarding & 50.8 & $36.8^{* *}$ \\
\hline Mixed day & 10.2 & $27.7^{* *}$ \\
\hline \multicolumn{3}{|l|}{ Level of schooling } \\
\hline Form one & 40.5 & $27.5^{* *}$ \\
\hline Form two & 24.3 & $28.7^{*}$ \\
\hline Form three & 27.0 & $32.4^{* *}$ \\
\hline Form four & 7.9 & $11.0^{* *}$ \\
\hline Missing & 0.4 & 0.3 \\
\hline \multicolumn{3}{|l|}{ Living arrangements } \\
\hline Biological parents & 88.8 & $74.5^{* *}$ \\
\hline Relative & 7.5 & $13.1^{* *}$ \\
\hline Alone & 1.3 & $6.3^{* *}$ \\
\hline Friends/other & 1.7 & $4.8^{* *}$ \\
\hline Missing & 0.7 & 1.4 \\
\hline
\end{tabular}

\section{Need for HIV and AIDS information}

Findings from the formative research showed that students, teachers, and parents/guardians were all in agreement on the need to provide in-school young people with HIV and AIDS information. This is supported by the following quotes:

If I know you bave HIV then I see you like you are a devil.. Some people need to be advised, they need the information (Student).

Schools should come together and give students topics to create skits, expressing their thoughts on HIV and AIDS (School Teacher).

They need to be tanght [about HIV/AIDS] in school, that would be very good. At least if they are tanght in school, then they will see that it is not just parents saying this for nothing. If they get this information at home and at school, they will finally get it [act responsibly] (Parent).

The questions that the students placed in the drop boxes were further indications of the need for more information on HIV and AIDS. The questions revolved around HIV transmission, diagnosis, symptoms, disclosure, testing, counseling, care and support services. The following are sample questions that were retrieved from the drop boxes:

My aunt died of HIV I AIDS five months ago after giving birth to a child. The child is now having a skin disease, is this AIDS?

What would you do if you found out that you were HIV positive when you are in bigh school?

I would like to get tested for HIVI AIDS but I am very afraid, how do I overcome the fear? 
What should someone do if he/ she is raped by their father who is HIV positive and is afraid to tell their mother because the father has threatened him/ her?

If a relative is infected with HIV and you happen to be the only family member aware, what are you supposed to do?

Among students who participated in the self-administered interviews at baseline, $82 \%$ indicated that they would like to receive information on HIV and AIDS at school. Those who indicated that they need such information were further asked what kind of information they would like to receive. The most commonly cited pieces of information were how to avoid being infected, the importance of being tested for HIV, how to access treatment and care if infected, how to live positively if infected, how HIV and AIDS affect the body, how HIV is acquired, and where to get tested (Figure 1).

Figure 1: Type of information on HIV and AIDS students would like to receive at school at baseline

\begin{tabular}{|r|r|r|r|}
\hline How to avoid being infected \\
How to access treatment and care \\
How it affects the body \\
Where to get tested
\end{tabular}

\section{Need for other sexual and reproductive health information}

Besides HIV and AIDS information, feedback from students indicated the need for other sexual and reproductive health information. Some of the questions from the drop boxes, for instance, were on issues of self-control, responsible sexual behavior, sexual negotiation, sexual abuse, and peer pressure. The following excerpts highlight such need:

You have a problem and yourparents are dead. A sugar mummy comes and helps you out and in return, she wants to have sex with you. What do you do to avoid such a scenario?

I am a 16 year old girl and in form two. I started having a boyfriend just for 'practice' and I became perfect and I now have many boyfriends from different schools. From there I got involved with baving sex with older men and this is becoming a problem to me. Please help me because this has affected me mentally and even physically.

My teacher proposed sex to me, should I accept if she suggests we use a condom?

What should you do if you were raped and do not have any trustworthy person to tell and your parents are out of the question?

I do not want to be in a relationship till I finish university but there is this boy who keeps asking me to relate with him. What do I do? 


\section{Knowledge about HIV and AIDS}

Students who participated in the self-administered interviews were asked about the modes of HIV transmission and whether they knew of a place where one can get tested. Among students in classes that participated in baseline and endline interviews, there were no significant differences in the proportions of students that reported knowledge of some modes of HIV transmission between the two surveys (Table 4). For knowledge of other modes of transmission and where to get tested for HIV, the proportions were significantly lower at endline than at baseline. Nonetheless, at endline, the proportions of students who had read the comic books that reported knowledge of the various modes of HIV transmission and of where to get tested were significantly higher than the proportions of those who did not obtain or read the materials. These findings are consistent for both male and female students (Table 4).

\begin{tabular}{|c|c|c|c|c|}
\hline \multicolumn{5}{|c|}{ Male students } \\
\hline & \multicolumn{2}{|c|}{ Point of study } & \multicolumn{2}{|c|}{ Endline } \\
\hline Indicators of knowledge & $\begin{array}{r}\text { Baseline } \\
(\%)\end{array}$ & $\begin{array}{r}\text { Endline } \\
(\%)\end{array}$ & $\begin{array}{r}\text { Read comic books } \\
(\%)\end{array}$ & $\begin{array}{r}\text { Did not obtain/read } \\
\text { comic books (\%) }\end{array}$ \\
\hline Mode of HIV transmission ${ }^{a}$ & $(\mathrm{~N}=1,777)$ & $(\mathrm{N}=852)$ & $(\mathrm{N}=1,036)$ & $(\mathrm{N}=317)$ \\
\hline Unprotected sex & 92.0 & $89.0^{*}$ & 93.2 & $77.0^{* *}$ \\
\hline Contaminated instruments & 66.9 & 64.8 & 70.2 & $46.4^{* *}$ \\
\hline Sharp objects/instruments & 69.8 & 66.1 & 70.7 & $50.5^{\star *}$ \\
\hline Mother-to-child & 72.1 & $67.0^{* *}$ & 71.7 & $49.2^{* *}$ \\
\hline Blood transfusion/accidents & 73.6 & $69.4^{*}$ & 75.4 & $48.9^{* *}$ \\
\hline $\begin{array}{l}\text { Knows where to get tested/ } \\
\text { counseled for HIV }\end{array}$ & $(\mathrm{N}=1,777)$ & $(\mathrm{N}=852)$ & $(\mathrm{N}=1,036)$ & $(\mathrm{N}=317)$ \\
\hline Yes & 85.8 & $77.7^{* \star}$ & 84.9 & $65.3^{* *}$ \\
\hline No & 10.6 & $17.4^{* *}$ & 12.2 & $22.1^{* *}$ \\
\hline Missing & 3.6 & 5.2 & 2.9 & $12.6^{* *}$ \\
\hline \multicolumn{5}{|c|}{ Female students } \\
\hline Mode of HIV transmissiona & $(\mathrm{N}=1,622)$ & $(\mathrm{N}=959)$ & $(\mathrm{N}=1,289)$ & $(\mathrm{N}=272)$ \\
\hline Unprotected sex & 92.4 & 91.2 & 94.6 & $81.6^{* *}$ \\
\hline Contaminated instruments & 67.1 & 66.7 & 69.3 & $52.2^{* *}$ \\
\hline Sharp objects/instruments & 72.0 & $67.1^{* *}$ & 72.1 & $57.4^{\star \star}$ \\
\hline Mother-to-child & 74.2 & $70.3^{*}$ & 76.0 & $61.0^{* *}$ \\
\hline Blood transfusion/accidents & 77.9 & $73.8^{*}$ & 78.0 & $61.8^{* *}$ \\
\hline $\begin{array}{l}\text { Knows where to get tested/ } \\
\text { counseled for HIV }\end{array}$ & $(\mathrm{N}=1,622)$ & $(\mathrm{N}=959)$ & $(\mathrm{N}=1,289)$ & $(N=272)$ \\
\hline Yes & 88.2 & $81.8^{* *}$ & 88.0 & $67.7^{* *}$ \\
\hline No & 8.1 & $14.9^{* \star}$ & 10.6 & $19.9^{* *}$ \\
\hline Missing & 3.6 & 3.3 & 1.5 & $12.5^{* *}$ \\
\hline
\end{tabular}


At endline, students who had read the comic books were further asked whether the information obtained from the materials changed their thinking or behavior regarding sexual and reproductive health including HIV and AIDS. Slightly more than three-quarters (76\%) reported such change with no significant difference between male and female students (76\% in each case). The most commonly cited change brought about by the comic books was that the students learnt more about HIV and AIDS, which was mentioned by $71 \%$ of the students who read the materials $73 \%$ of male and $68 \%$ of female students; $\mathrm{p}<0.05)$. Furthermore, improved knowledge of modes of HIV transmission among students who read the comic books is further supported by the feedback obtained through the drop boxes as the following quotes indicate:

From reading Kuwa Shujaa, I know that having sex with a virgin to heal HIVIAIDS is a myth and cannot be true.

I leant from Kuwa Shujaa that ARVs do not cure HIV/AIDS but they only help the infected to live longer and a bealthy life.

You have been of great help to me and my friends in school. You answered some of our questions like if a person can be infected with HIV by kissing. Thanks and keep spreading the information about HIV/AIDS.

Kuwa Shujaa helped me learn that HIV cannot be spread by shaking hands and that you cannot tell someone's status by looking at their physical appearance... Thank you for giving this important information.

\section{Communication about HIV and AIDS}

In the structured self-administered interviews, indicators of communication about HIV and AIDS were captured through questions on whether the students had ever talked about testing and counseling with anyone, who they talked to, whether they would inform their parents/guardians about the decision to get tested and the test results, and among those who had ever been tested, whether they informed their parents/guardians about it. Among students from classes that participated in both baseline and endline interviews, the proportions that had ever talked about testing and counseling with anyone was significantly lower at endline than at baseline for both male and female students (Tables 5 and 6 ).

At endline, however, the proportion of students that had ever talked about testing and counseling with anyone was significantly higher among those who read the comic books than among those who did not obtain or read the materials. This also applies to both male and female students (Tables 5 and 6). With respect to the other indicators of communication about HIV and AIDS that were considered, there were no significant differences between baseline and endline or between those who read the comic books and those who did not (Tables 5 and 6). 


\begin{tabular}{|c|c|c|c|c|}
\hline \multirow[b]{2}{*}{ Characteristics } & \multicolumn{2}{|c|}{ Point of study } & \multicolumn{2}{|c|}{ Endline } \\
\hline & $\begin{array}{r}\text { Baseline } \\
(\%)\end{array}$ & $\begin{array}{r}\text { Endline } \\
\qquad(\%)\end{array}$ & $\begin{array}{r}\text { Read comic books } \\
(\%)\end{array}$ & $\begin{array}{r}\text { Did not obtain/ read } \\
\text { comic books (\%) }\end{array}$ \\
\hline $\begin{array}{l}\text { Ever talked about HIV testing/ } \\
\text { counseling with anyone }\end{array}$ & $(\mathrm{N}=1,777)$ & $(\mathrm{N}=852)$ & $(\mathrm{N}=1,036)$ & $(N=317)$ \\
\hline Yes & 57.5 & $50.4^{* *}$ & 54.3 & $43.5^{* *}$ \\
\hline No & 35.9 & $44.0^{* *}$ & 41.3 & 42.3 \\
\hline Missing & 6.7 & 5.6 & 4.4 & $14.2^{* *}$ \\
\hline $\begin{array}{l}\text { Would inform parent/guardian } \\
\text { about decision to get testeda }\end{array}$ & $(\mathrm{N}=1,254)$ & $(\mathrm{N}=565)$ & $(\mathrm{N}=783)$ & $(N=175)$ \\
\hline Yes & 56.3 & 59.5 & 62.6 & 62.3 \\
\hline No & 37.9 & 33.8 & 31.3 & 25.7 \\
\hline Missing & 5.8 & 6.7 & 6.1 & $12.0^{* *}$ \\
\hline $\begin{array}{l}\text { Would inform parent/guardian } \\
\text { about test results }{ }^{b}\end{array}$ & $(\mathrm{~N}=1,141)$ & $(\mathrm{N}=505)$ & $(\mathrm{N}=708)$ & $(N=147)$ \\
\hline Yes & 71.1 & 73.5 & 75.1 & 79.6 \\
\hline No & 27.6 & 24.6 & 23.2 & 16.3 \\
\hline Missing & 1.3 & 2.0 & 1.7 & 4.1 \\
\hline $\begin{array}{l}\text { Informed parent(s)/guardian(s) } \\
\text { about decision to get testedc }\end{array}$ & $(\mathrm{N}=438)$ & $(\mathrm{N}=240)$ & $(\mathrm{N}=264)$ & $(\mathrm{N}=86)$ \\
\hline Yes & 50.2 & 51.3 & 53.4 & 64.0 \\
\hline No & 43.8 & 39.2 & 38.6 & 27.9 \\
\hline Missing & 5.9 & 9.6 & 8.0 & 8.1 \\
\hline \multicolumn{5}{|c|}{$\begin{array}{l}\text { Notes: Percentages may not sum to } 100 \text { due to rounding; among those who would accept HIV testing; } \\
{ }^{b} \text { Among those who would accept test results; ' }{ }^{*} \text { Among those who had ever been tested for HIV; }{ }^{*} p<0.05 ; \\
{ }^{* *} p<0.01 \text {. }\end{array}$} \\
\hline
\end{tabular}

At endline, a significantly higher proportion of students who read the comic books reported ever talking to classmates or friends about HIV testing and counseling compared to those who did not obtain or read the materials ( $56 \%$ versus $45 \% ; \mathrm{p}<0.01$; Figure 2 ). Although the proportions that reported ever talking to parents/guardians or teachers were higher among students who read the comic books compared to those who did not obtain or read the materials, the differences were not statistically significant (Figure 2). Communication about HIV and AIDS with other persons (friends, family members and teachers) was also cited by $47 \%$ of the students who had read the comic books at endline as one of the changes brought about by the materials with no significant difference between male and female students ( $46 \%$ and $48 \%$ respectively). 


\begin{tabular}{|c|c|c|c|c|}
\hline \multirow[b]{2}{*}{ Characteristics } & \multicolumn{2}{|c|}{ Point of study } & \multicolumn{2}{|c|}{ Endline } \\
\hline & Baseline (\%) & Endline (\%) & $\begin{array}{r}\text { Read comic } \\
\text { books (\%) }\end{array}$ & $\begin{array}{l}\text { Did not obtain/ read } \\
\text { comic books (\%) }\end{array}$ \\
\hline $\begin{array}{l}\text { Ever talked about HIV testing/ } \\
\text { counseling with anyone }\end{array}$ & $(\mathrm{N}=1,622)$ & $(\mathrm{N}=959)$ & $(\mathrm{N}=1,289)$ & $(\mathrm{N}=272)$ \\
\hline Yes & 66.9 & $56.4^{* *}$ & 61.0 & $50.0^{* \star}$ \\
\hline No & 27.5 & $38.4^{* *}$ & 34.8 & 35.3 \\
\hline Missing & 5.6 & 5.2 & 4.2 & $14.7^{* *}$ \\
\hline $\begin{array}{l}\text { Would inform parent/guardian } \\
\text { about decision to get testeda }\end{array}$ & $(\mathrm{N}=1,344)$ & $(\mathrm{N}=738)$ & $(\mathrm{N}=1,079)$ & $(\mathrm{N}=167)$ \\
\hline Yes & 63.8 & 66.9 & 70.8 & 63.5 \\
\hline No & 28.4 & 26.6 & 24.3 & 21.6 \\
\hline Missing & 7.7 & 6.5 & 4.9 & $15.0^{* \star}$ \\
\hline $\begin{array}{l}\text { Would inform parent/guardian } \\
\text { about test results }{ }^{b}\end{array}$ & $(\mathrm{~N}=1,255)$ & $(\mathrm{N}=680)$ & $(\mathrm{N}=1,009)$ & $(\mathrm{N}=138)$ \\
\hline Yes & 77.1 & 77.5 & 81.2 & 76.1 \\
\hline No & 20.2 & 21.6 & 17.4 & 20.3 \\
\hline Missing & 2.0 & 0.9 & 1.4 & 3.6 \\
\hline $\begin{array}{l}\text { Informed parent(s)/guardian(s) } \\
\text { about decision to get tested }\end{array}$ & $(\mathrm{N}=425)$ & $(\mathrm{N}=259)$ & $(\mathrm{N}=309)$ & $(\mathrm{N}=69)$ \\
\hline Yes & 65.4 & 64.5 & 69.3 & 66.7 \\
\hline No & 27.8 & 29.0 & 24.3 & 29.0 \\
\hline Missing & 6.8 & 6.6 & 6.5 & 4.4 \\
\hline
\end{tabular}

These findings were further supported by the qualitative feedback from teachers and students. The teachers, for instance, reported that students talked about HIV and AIDS at school more freely than before. Students not only reported openly talking about HIV and AIDS but also recognized the importance of the comic books for improving parent-child communication as shown by the following excerpts:

This book is cool, inspiring and very educative. The stories are real and I am glad I can learn a lot now. I am even open now talking about HIV/AIDS...Please lengthen the stories. Thank you very much.

The 'Mwelekeo wa Warari' [parents' guide] is excellent in educating parents on how to relate with their sons and daughters.

The book is interesting and talks about real life issues. I have learned so many things from the book. Things about HIV / AIDS, parent-child relationship and peer pressure. This is a very good way of educating students. We would like you to come to our school more often. 
Figure 2: Percent distribution of students who ever talked to anyone about HIV testing and counseling by the persons they talked to, endline

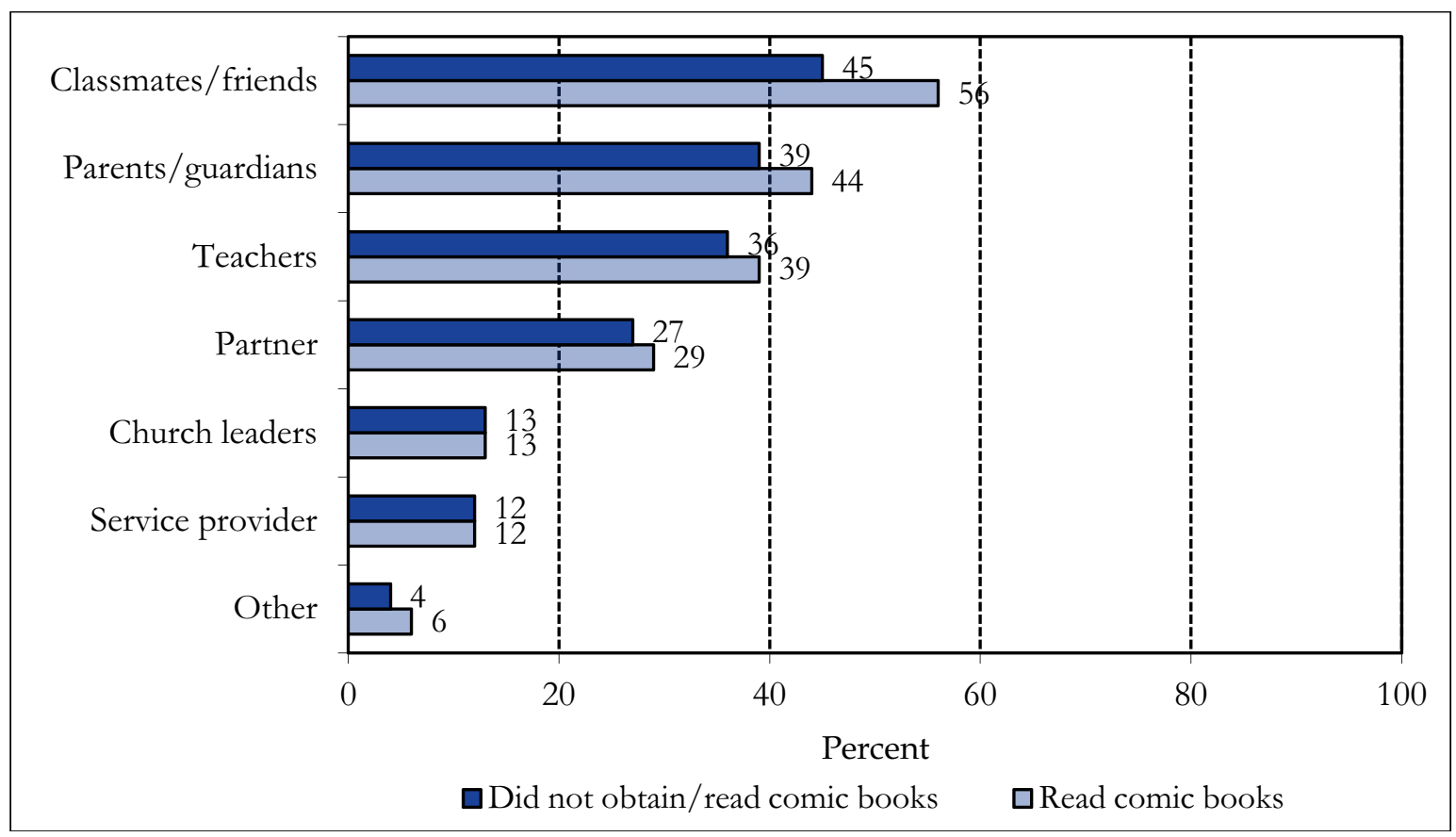

Note: The question on who the respondent talked to allowed for multiple responses.

\section{Attitudes towards people living with HIV}

Students were asked whether they thought that children living with HIV should be allowed in school, whether they knew of a fellow student who was living with HIV and if so, what their reactions were towards such students. Among male and female students from classes that participated in both the baseline and endline interviews, the proportions that indicated that children living with HIV should be allowed in school was significantly lower at endline than at baseline (Table 7). At endline, however, the proportion of students reporting that children living with HIV should be allowed in school was significantly higher among those who read the comic books than among those who did not obtain or read the materials.

Among students in classes that participated in both baseline and endline interviews and who knew of a fellow student who was living with HIV, the proportions reporting positive reactions at endline was not significantly different from that at baseline (Table 7). Positive reactions included showing love and compassion, counseling the student, assisting him/her with academic work, and praying for him/her. Nonetheless, the proportion of male students reporting negative reactions was significantly higher among those who did not obtain or read the comic books than among those who read the materials. Negative reactions included avoiding the student, ridiculing or teasing $\mathrm{him} / \mathrm{her}$, harassing or assaulting him/her, telling others about it, and advising the student to leave school. Among female students, although the proportion reporting positive reactions at endline was higher among those who read the comic books than among those who did not obtain or read the materials, the difference was not statistically significant perhaps due to the small number of cases (Table 7). 


\begin{tabular}{|c|c|c|c|c|}
\hline \multicolumn{5}{|c|}{ Male students } \\
\hline & \multicolumn{2}{|c|}{ Point of study } & \multicolumn{2}{|c|}{ Endline } \\
\hline Characteristics & $\begin{array}{r}\text { Baseline } \\
(\%)\end{array}$ & $\begin{array}{r}\text { Endline } \\
(\%)\end{array}$ & $\begin{array}{r}\text { Read comic books } \\
(\%)\end{array}$ & $\begin{array}{r}\text { Did not obtain/read } \\
\text { comic books (\%) }\end{array}$ \\
\hline $\begin{array}{l}\text { HIV-positive children should be allowed in } \\
\text { school }\end{array}$ & $(\mathrm{N}=1,777)$ & $(\mathrm{N}=852)$ & $(\mathrm{N}=1,036)$ & $(\mathrm{N}=317)$ \\
\hline Yes & 87.3 & $83.5^{* *}$ & 92.0 & $67.8^{* *}$ \\
\hline No & 9.8 & 9.9 & 5.9 & $15.8^{* *}$ \\
\hline Missing & 2.9 & $6.7^{* *}$ & 2.1 & $16.4^{* *}$ \\
\hline Knows HIV-positive student & $(\mathrm{N}=1,777)$ & $(\mathrm{N}=852)$ & $(\mathrm{N}=1,036)$ & $(\mathrm{N}=317)$ \\
\hline Yes & 6.7 & 8.2 & 5.7 & $12.9^{\star *}$ \\
\hline No & 85.4 & $82.4^{*}$ & 89.2 & $64.0^{* *}$ \\
\hline Missing & 7.9 & 9.4 & 5.1 & $23.0^{* *}$ \\
\hline Reaction toward HIV-positive student & $(\mathrm{N}=119)$ & $(\mathrm{N}=70)$ & $(\mathrm{N}=59)$ & $(\mathrm{N}=41)$ \\
\hline No reaction & 32.8 & 30.0 & 33.9 & 29.3 \\
\hline Positive reaction & 38.7 & 40.0 & 45.8 & 39.0 \\
\hline Negative reaction & 17.7 & 18.6 & 8.5 & $24.4^{*}$ \\
\hline Other/neutral reactions & 5.0 & 2.9 & 3.4 & 2.4 \\
\hline Missing & 5.9 & 8.6 & 8.5 & 4.9 \\
\hline \multicolumn{5}{|c|}{ Female students } \\
\hline $\begin{array}{l}\text { HIV-positive children should be allowed in } \\
\text { school }\end{array}$ & $(\mathrm{N}=1,622)$ & $(\mathrm{N}=959)$ & $(\mathrm{N}=1,289)$ & $(\mathrm{N}=272)$ \\
\hline Yes & 92.8 & $89.2^{* *}$ & 95.7 & $75.4^{* *}$ \\
\hline No & 5.1 & 6.4 & 3.6 & $9.9^{* *}$ \\
\hline Missing & 2.1 & $4.5^{* *}$ & 0.7 & $14.7^{* *}$ \\
\hline Knows HIV-positive student & $(\mathrm{N}=1,622)$ & $(\mathrm{N}=959)$ & $(\mathrm{N}=1,289)$ & $(\mathrm{N}=272)$ \\
\hline Yes & 6.2 & $10.0^{* *}$ & 8.4 & 8.8 \\
\hline No & 86.1 & $81.7^{* *}$ & 88.1 & $66.2^{* *}$ \\
\hline Missing & 7.6 & 8.3 & 3.5 & $25.0^{* *}$ \\
\hline Reaction toward HIV-positive student & $(\mathrm{N}=101)$ & $(\mathrm{N}=96)$ & $(\mathrm{N}=108)$ & $(\mathrm{N}=24)$ \\
\hline No reaction & 17.8 & 19.8 & 14.8 & 25.0 \\
\hline Positive reaction & 61.4 & 62.5 & 73.2 & 54.2 \\
\hline Negative reaction & 13.9 & 7.3 & 5.6 & 8.3 \\
\hline Other/neutral reactions & 4.0 & 5.2 & 3.7 & 4.2 \\
\hline Missing & 3.0 & 5.2 & 2.8 & 8.3 \\
\hline Notes: Percentages may not sum to 100 & e to roundin & ; ${ }^{*} p<0.05$ & $p<0.01$ & \\
\hline
\end{tabular}

With respect to self-reported changes brought about by the comic books among students who read the materials at endline, $52 \%$ mentioned positive changes in their attitudes towards people living with HIV (51\% of male and $54 \%$ of female students; $\mathrm{p}=0.30$ ). Feedback obtained from students through the drop boxes further supported these findings as exemplified by the following quotes:

Personally I am a victim not because I am infected but because I had to go to primary school with HIVinfected pupils whom I was afraid of. The comic has challenged me to accept them and evaluate myself.

Kuwa Shujaa comic book made me change my perspective of viewing HIVIAIDS infected people in society. Please lengthen the stories.

From Kuwa Shujaa, I learnt to treat the HIV positive as we would want people to treat us now and if we were HIV positive, care for them and feed them a balance diet.

I am very happy because Kuwa Shujaa made me know how to live with people suffering from HIVIAIDS. We should not discriminate against them because it is not their wish to be HIV positive. 


\section{Uptake of HIV testing and counseling}

Uptake of HIV testing and counseling was measured by questions on whether the students would accept the services if offered, whether they had ever been tested and if so, how long ago before the interview date they were tested. Among male students from classes that participated in both baseline and endline interviews, there were no significant differences in the proportions that would accept testing, counseling or test results, or in the proportion that had ever been tested between the two surveys (Table 8). Among female students from similar classes, the proportion that would accept HIV testing was significantly lower at endline than at baseline (Table 9). Similar to male students, however, differences between the two surveys with respect to acceptability of counseling or test results and whether they had ever been tested are not statistically significant. In addition, the proportions of male or female students that had been tested within the last five months preceding the survey was significantly lower at endline than at

\begin{tabular}{|c|c|c|c|c|}
\hline & \multicolumn{2}{|c|}{ Point of study } & \multicolumn{2}{|c|}{ Endline } \\
\hline Characteristics & $\begin{array}{r}\text { Baseline } \\
(\%)\end{array}$ & $\begin{array}{r}\text { Endline } \\
(\%)\end{array}$ & $\begin{array}{r}\text { Read comic } \\
\text { books (\%) }\end{array}$ & $\begin{array}{r}\text { Did not } \\
\text { obtain/read } \\
\text { comic books (\%) }\end{array}$ \\
\hline $\begin{array}{l}\text { Would accept HIV } \\
\text { testing if offered }\end{array}$ & $(\mathrm{N}=1,777)$ & $(\mathrm{N}=852)$ & $(\mathrm{N}=1,036)$ & $(\mathrm{N}=317)$ \\
\hline Yes & 68.1 & 66.3 & 75.6 & $55.2^{* \star}$ \\
\hline No & 26.2 & 28.8 & 21.0 & $32.5^{\star \star}$ \\
\hline Missing & 5.7 & 4.9 & 3.4 & $12.3^{\star \star *}$ \\
\hline $\begin{array}{l}\text { Would accept } \\
\text { counseling before } \\
\text { testing for HIV }\end{array}$ & $(\mathrm{N}=1,210)$ & $(N=565)$ & $(N=783)$ & $(\mathrm{N}=175)$ \\
\hline Yes & 81.5 & 81.2 & 84.7 & $72.6^{* \star}$ \\
\hline No & 12.7 & 12.7 & 10.1 & $16.0^{*}$ \\
\hline Missing & 5.8 & 6.0 & 5.2 & $11.4^{* *}$ \\
\hline $\begin{array}{l}\text { Would receive results } \\
\text { if tested for HIV }\end{array}$ & $(\mathrm{N}=1,210)$ & $(N=565)$ & $(\mathrm{N}=783)$ & $(\mathrm{N}=175)$ \\
\hline Yes & 91.5 & 89.4 & 90.4 & $84.0^{*}$ \\
\hline No & 3.6 & 3.9 & 3.6 & 4.6 \\
\hline Missing & 4.9 & 6.7 & 6.0 & $11.4^{*}$ \\
\hline $\begin{array}{l}\text { Ever been tested for } \\
\text { HIV }\end{array}$ & $(\mathrm{N}=1,777)$ & $(\mathrm{N}=852)$ & $(\mathrm{N}=1,036)$ & $(\mathrm{N}=317)$ \\
\hline Yes & 24.7 & 28.2 & 25.5 & 27.1 \\
\hline No & 69.8 & $65.0^{*}$ & 71.0 & $55.5^{* \star}$ \\
\hline Missing & 5.5 & 6.8 & 3.6 & $17.4^{* \star}$ \\
\hline $\begin{array}{l}\text { Tested for HIV within } \\
\text { last five months }\end{array}$ & $(\mathrm{N}=438)$ & $(\mathrm{N}=240)$ & $(\mathrm{N}=264)$ & $(\mathrm{N}=86)$ \\
\hline Yes & 45.7 & $34.6^{* *}$ & 34.1 & 32.6 \\
\hline No & 50.9 & $60.0^{*}$ & 61.7 & 60.5 \\
\hline Missing & 3.4 & 5.4 & 4.2 & 7.0 \\
\hline Notes: aPercentage & y not sum & 100 due & rounding; * $p$ & $<0.05 ;{ }^{* *} p<0.01$. \\
\hline
\end{tabular}
baseline (Tables 8 and 9).

At endline, the proportions of students that indicated that they would accept testing, counseling or test results were significantly higher among those who read the comic books than among those who did not (Tables 8 and 9). There was, however, no significant difference between the two groups of students in the proportion that had ever been tested for HIV. Moreover, although the proportion of female students that was tested within the last five months before the interview was higher among those who read the comic books than among those who did not obtain or read the materials, the difference was not statistically significant (Table 9). 


\begin{tabular}{|c|c|c|c|c|}
\hline \multirow[b]{2}{*}{ Characteristics } & \multicolumn{2}{|c|}{ Point of study } & \multicolumn{2}{|c|}{ Endline } \\
\hline & Baseline (\%) & Endline (\%) & $\begin{array}{r}\text { Read comic } \\
\text { books (\%) }\end{array}$ & $\begin{array}{r}\text { Did not obtain/read } \\
\text { comic books (\%) }\end{array}$ \\
\hline Would accept HIV testing if offered & $(\mathrm{N}=1,622)$ & $(\mathrm{N}=959)$ & $(\mathrm{N}=1,289)$ & $(\mathrm{N}=272)$ \\
\hline Yes & 80.7 & $77.0^{*}$ & 83.7 & $61.4^{* *}$ \\
\hline No & 14.2 & $17.9^{*}$ & 13.4 & $24.6^{* *}$ \\
\hline Missing & 5.1 & 5.1 & 2.9 & $14.0^{* *}$ \\
\hline $\begin{array}{l}\text { Would accept counseling before } \\
\text { testing for HIV }\end{array}$ & $(\mathrm{N}=1,309)$ & $(\mathrm{N}=738)$ & $(\mathrm{N}=1,079)$ & $(\mathrm{N}=167)$ \\
\hline Yes & 81.4 & 82.1 & 85.6 & $77.8^{* *}$ \\
\hline No & 12.0 & 11.3 & 8.8 & 10.2 \\
\hline Missing & 6.7 & 6.6 & 5.6 & $12.0^{* *}$ \\
\hline Would receive results if tested for HIV & $(\mathrm{N}=1,309)$ & $(\mathrm{N}=738)$ & $(\mathrm{N}=1,079)$ & $(\mathrm{N}=167)$ \\
\hline Yes & 92.1 & 92.1 & 93.5 & $82.6^{* *}$ \\
\hline No & 2.1 & 2.9 & 2.4 & 4.8 \\
\hline Missing & 5.8 & 5.0 & 4.1 & $12.6^{* *}$ \\
\hline Ever been tested for HIV & $(\mathrm{N}=1,622)$ & $(\mathrm{N}=959)$ & $(\mathrm{N}=1,289)$ & $(\mathrm{N}=272)$ \\
\hline Yes & 26.2 & 27.0 & 24.0 & 25.4 \\
\hline No & 68.1 & 66.3 & 72.9 & $53.7^{* *}$ \\
\hline Missing & 5.7 & 6.7 & 3.1 & $21.0^{* *}$ \\
\hline Tested for HIV within last five months & $(\mathrm{N}=425)$ & $(\mathrm{N}=259)$ & $(\mathrm{N}=309)$ & $(\mathrm{N}=69)$ \\
\hline Yes & 51.1 & $35.1^{* *}$ & 35.9 & 29.0 \\
\hline No & 44.0 & $59.5^{* *}$ & 61.2 & 59.4 \\
\hline Missing & 4.9 & 5.4 & 2.9 & $11.6^{* *}$ \\
\hline
\end{tabular}

Results based on the question on the changes brought about by the comic books among students who read the materials at endline show that $47 \%$ mentioned reduced fear of getting tested for HIV $(44 \%$ of male and $50 \%$ of female students; $\mathrm{p}<0.05)$ while $22 \%$ reported that they got tested $(20 \%$ of male and $24 \%$ of female students; $\mathrm{p}=0.11$ ). This is also supported by the feedback obtained from students through the drop boxes, for example:

After reading Kuwa Shujaa, I am not afraid of getting tested. I can now go and get tested.

I love your comic book because it is very inspiring. I am planning to test for HIV/AIDS though I am a virgin just to know my status and avoid being hazardous to the community.

Thank you very much Kuwa Shujaa. My request is you come back to our school and do HIVIAIDS testing so that you can help the infected if any before it is too late.

Kuwa Shujaa has opened my eyes and helped me know that every person going or seen in or around a VCT is not HIV positive... When I read Kuwa Shujaa, I went for test and I am happy that I am now aware of my status. 


\section{Sexual behavior}

Among all students who participated in baseline interviews, 29\% reported having ever had sex (42\% of male and $15 \%$ of female students; $\mathrm{p}<0.01$ ). Of those who had ever had sex, $81 \%$ reported consensual first sex, that is, both were willing or wanted to have sex ( $86 \%$ of male and $66 \%$ of female students; $\mathrm{p}<0.01)$. Forty eight percent of those who had consensual first sex used a method to prevent pregnancy or sexually transmitted infections (STIs) including HIV (44\% of male and $62 \%$ of female students; $\mathrm{p}<0.01$ ). The proportion of students reporting having ever had sex at endline was not significantly different from that at baseline $(27 \%$ of all students who participated in the interviews; $39 \%$ of male and $17 \%$ of female students). A similar pattern was noted for the proportions reporting consensual first sex $(80 \%$ of those who had ever had sex; $86 \%$ of male and $67 \%$ of female students) and the proportions that used a preventive method at first sex (48\% of those who had consensual first sex; $45 \%$ of male and $54 \%$ of female students).

Among male students in classes that participated in both baseline and endline interviews, there were no significant differences between the two surveys in the proportions that had sex within the last one month preceding the interviews or in the proportions that used a preventive method at last sex (Table 10). In contrast, among female students in classes that participated in both interviews, the proportion that had sex in the last one month was significantly lower at endline than at baseline. However, similar to male students, there was no significant difference in the proportion that used a preventive method at last sex between baseline and endline.

At endline, the proportions of male or female students that had sex within the last one month before the interview was significantly lower among those who read the comic books than among those who did not obtain or read the materials (Table 10). Although the proportions that used a preventive method at last sex were higher among those who read the comic books than among those who did not obtain or read the materials, the differences were not statistically significant. Nonetheless, learning about responsible sexual behavior was the second most commonly mentioned change that students who had read the comic books reported at endline, with $64 \%$ of the students citing it (57\% of male and $70 \%$ of female students; $\mathrm{p}<0.01)$.

\begin{tabular}{|c|c|c|c|c|}
\hline \multicolumn{5}{|c|}{$\begin{array}{l}\text { Table 10: Percent distribution of male a } \\
\text { recent sexual behavior }\end{array}$} \\
\hline \multicolumn{5}{|c|}{$\begin{array}{ll} & \text { Male students } \\
\end{array}$} \\
\hline & \multicolumn{2}{|c|}{ Point of study } & \multicolumn{2}{|c|}{ Endline } \\
\hline Characteristics & $\begin{array}{r}\text { Baseline } \\
(\%)\end{array}$ & $\begin{array}{r}\text { Endline } \\
\qquad(\%)\end{array}$ & $\begin{array}{r}\text { Read } \\
\text { comic } \\
\text { books } \\
(\%)\end{array}$ & $\begin{array}{r}\text { Did not } \\
\text { obtain/read } \\
\text { comic } \\
\text { books (\%) }\end{array}$ \\
\hline $\begin{array}{l}\text { Had sex last one month } \\
\text { before the survey }\end{array}$ & $(\mathrm{N}=750)$ & $\begin{array}{r}(\mathrm{N}=361 \\
)\end{array}$ & $(\mathrm{N}=386)$ & $(\mathrm{N}=137)$ \\
\hline Yes & 35.2 & 29.9 & 25.4 & $35.0^{*}$ \\
\hline No & 62.3 & 67.9 & 72.8 & $59.9^{* *}$ \\
\hline Missing & 2.5 & 2.2 & 1.8 & $5.1^{*}$ \\
\hline $\begin{array}{l}\text { Used a method to } \\
\text { prevent pregnancy or } \\
\text { STIs at last sex }\end{array}$ & $(\mathrm{N}=750)$ & $(\mathrm{N}=361$ & $(\mathrm{N}=386)$ & $(\mathrm{N}=137)$ \\
\hline Yes & 51.6 & 53.5 & 52.3 & 47.5 \\
\hline No & 43.9 & 44.0 & 45.1 & 48.2 \\
\hline Missing & 4.5 & 2.5 & 2.6 & 4.4 \\
\hline \multicolumn{5}{|c|}{ Female students } \\
\hline $\begin{array}{l}\text { Had sex last one month } \\
\text { before the survey }\end{array}$ & $(\mathrm{N}=247)$ & $\begin{array}{r}(\mathrm{N}=210 \\
)\end{array}$ & $(\mathrm{N}=189)$ & $(\mathrm{N}=69)$ \\
\hline Yes & 48.6 & $37.6^{*}$ & 30.2 & $47.8^{* *}$ \\
\hline No & 48.6 & $59.1^{*}$ & 67.2 & $46.4^{* *}$ \\
\hline Missing & 2.8 & 3.3 & 2.7 & 5.8 \\
\hline $\begin{array}{l}\text { Used a method to } \\
\text { prevent pregnancy or } \\
\text { STIs at last sex }\end{array}$ & $(\mathrm{N}=247)$ & $(\mathrm{N}=210$ & $(\mathrm{N}=189)$ & $(\mathrm{N}=69)$ \\
\hline Yes & 55.5 & 56.2 & 55.6 & 47.8 \\
\hline No & 39.7 & 40.0 & 39.7 & 46.4 \\
\hline Missing & 4.9 & 3.8 & 4.8 & 5.8 \\
\hline $\begin{array}{l}\text { Notes: } \mathrm{STIS}=\text { sex } \\
\text { sum to } 100 \text { due to }\end{array}$ & * & . & . & \\
\hline
\end{tabular}


This was further supported by feedback obtained from students through the drop boxes as shown by the following excerpts:

Kuwa Shujaa has belped me learn that I can avoid sex by trying not to be idle.

To me it has helped me avoid peer pressure because when I read about Jipendo [character in the comic books], it is really discouraging peer pressure. Thank you very much and I would request for more comic books.

The characters in the comics are reaching out to us. Increase the number of pages and continue using celebrities like [name] who are examples to us youngsters. I believe Kuwa Shujaa will change lives of many and open eyes too.

\section{Discussion and summary of findings}

Although many sub-Saharan African countries that are affected by HIV and AIDS have developed education sector policies in response to the epidemic, there are still challenges in effectively addressing the issue in schools. This has largely been attributed to lack of appropriate leadership and coordination at the school level, limited training and skills update on HIV and AIDS among schoolbased caregivers (teachers, school nurses and matrons), absence of appropriate guidelines in some settings, and lack of coordination between the education, health and other sectors (Obare et al. 2009; Ward and Mendelsohn 2009).

Yet, schools comprise a large segment of the population that is at risk of experiencing poor SRH outcomes such as unplanned pregnancies and contracting STIs including HIV. In Kenya, for instance, although national guidelines exist for providing HIV services to various segments of the population, the education sector policy is silent on how the services can be provided to in-school youth. This pilot study therefore tested the feasibility of using youth-friendly channels to communicate HIV and AIDS messages to in-school young people with a view to improving their knowledge about the epidemic, enhancing communication about it, and promoting positive attitudes and behavior among them. Its major findings are as follows:

- Students need HIV and AIDS and other sexual and reproductive health information: Although there have been numerous behavior change communications programs aimed at mitigating the spread of HIV in Kenya, the study showed that many in-school young people still need accurate information not only on HIV-related topics but other sexual and reproductive health issues as well. This was evident from the formative research, the questions which were retrieved from the drop boxes, and from structured self-administered interviews. Questions on HIV and AIDS mainly revolved around transmission, diagnosis, disclosure, counseling, care and support while other SRH issues included self-control, responsible sexual behavior, sexual negotiation, sexual abuse and peer pressure. In addition, $82 \%$ and $79 \%$ of the students indicated at baseline and endline interviews respectively that they would like to receive information on HIV and AIDS at school.

- Using youth-friendly channels to communicate HIV and AIDS messages is feasible and acceptable to students: Nearly all students (97\%) who obtained and read the communications materials liked them with no significant difference by sex ( $96 \%$ of male and $97 \%$ of female students who read the materials). Moreover, qualitative feedback from students and teachers showed that the interventions were relevant and realistic to in-school youth. The acceptability of the interventions to students and teachers could largely be attributed to the involvement of various levels of education stakeholders (education managers, school principals, teachers, parents/guardians, and students) in the conceptualization and design of the activities. 
- There was increased knowledge of modes of HIV transmission and where to get tested for HIV among students exposed to the interventions: At endline, the proportions of male and female students that mentioned specific modes of HIV transmission were significantly higher among those who read the communications materials than among those who did not obtain or read them. Specific modes of HIV transmission that were mentioned included unprotected sex with an infected person, contaminated non-sterilized instruments, sharing sharp objects, from mother-to-child through pregnancy, delivery and breastfeeding, and through blood transfusion. In addition, the proportions of male and female students that knew where to get tested for HIV were significantly higher among those who read the materials than among those who did not obtain or read them. These findings are further supported by the feedback obtained from students through the drop boxes. The differences in the indicators between baseline and endline among students in classes that participated in both interviews did not, however, conform to expectations.

- There was increased communication about HIV and AIDS among students exposed to the interventions: Among male and female students who participated in the endline interviews, the proportions that ever talked about HIV testing and counseling with anyone were significantly higher among those who read the communications materials than among those who did not obtain or read them. In addition, the proportion of students that had ever talked to classmates or friends about HIV testing and counseling was significantly higher among those who read the materials than among those who did not obtain or read them. The findings were also consistent with the feedback obtained from students through the drop boxes. However, differences between baseline and endline indicators among students in classes that participated in both interviews were not in the expected directions.

- There were positive changes in attitudes towards people living with HIV among students exposed to the interventions: At endline, the proportions of male and female students reporting that children living with HIV should be allowed in school were significantly higher among those who read the communications materials than among those who did not obtain or read them. In addition, among male students who knew of a fellow student who was living with HIV, the proportion reporting negative reactions towards them (for example, avoiding, teasing, ridiculing, or harassing them) was significantly lower among those who read the materials than among those who did not obtain or read them. In addition, $73 \%$ of female students who knew of a fellow student who was living with HIV reported positive reactions towards them (for example, showing compassion, assisting, counseling or praying for them) compared to $54 \%$ of those who did not obtain or read the materials. Positive changes in attitudes towards people living with HIV were further supported by feedback obtained from students through the drop boxes. Baseline and endline comparisons of these indicators among students in classes that participated in both interviews did not, however, conform to expectations.

- There was reduced fear of getting tested for HIV among students exposed to the interventions: Among male and female students who participated in the endline interviews, the proportions that indicated that they would accept HIV testing, counseling or test results were significantly higher among those who read the communications materials than among those who did not obtain or read them. Although the proportion of female students that was tested for HIV within five months preceding endline interviews was higher among those who read the materials than among those who did not (36\% compared to $29 \%$ ), the difference was not statistically significant. The corresponding figures for male students were $34 \%$ among those who read the materials and 33\% among those who did not obtain or read them. This suggests that the interventions might have been more effective in reducing the fear of getting tested than in increasing the uptake of testing. Feedback obtained from students through the drop boxes 
also had more comments about reduced fear than about actual uptake of testing. Again, differences between baseline and endline indicators among students in classes that participated in both interviews were not in the expected direction.

- There were positive changes in the sexual behavior of students exposed to the interventions: At endline, the proportions of male or female students that had sex in the last one month (among those who had ever had sex) was significantly lower among those who read the communications materials than among those who did not obtain or read them. Moreover, although not statistically significant, the proportions of sexually active male or female students who used a method at last sex to prevent pregnancy or STIs including HIV and AIDS were higher among those who read the materials than among those who did not obtain or read them. This was also supported by the feedback obtained from students through the drop boxes. In addition, the proportion of female students in classes that participated in both baseline and endline interviews and who had sex in the last one month (among those who had ever had sex) was significantly lower in the second than in the first survey. Although the proportion of male students who had sex within the same period was lower at endline than at baseline, the difference was not statistically significant. Similarly, there were no significant differences between baseline and endline in the proportions of male or female students who used a preventive method at last sex.

\section{Challenges and limitations}

The pilot study experienced a few challenges and limitations as follows:

- Instances of student getting absorbed with the communications materials: Some teachers reported that a section of the students got absorbed with the communications materials at the expense of normal lessons. However, the teachers indicated that they intervened in such cases.

- Busy school schedules: Some of the activities had to be organized during weekends and in the evening when there were no lessons going on. This may have left out some students, especially in day schools. In addition, some teachers did not have sufficient time to fully read through the guides because of other duties.

- Difficulty in reaching parents/guardians of low socio-economic status with the information: Teachers reported that although parents/guardians who got the guides were positive about their educative content, most of those from low-income settings were illiterate and some did not even take keen interest in their children's education. In such cases, the guides may not have achieved the desired effect of improving communication about HIV and AIDS between parents/guardians and their children.

- The study was piloted only in urban secondary schools: Due to funding limitations, the study was piloted in secondary schools in Nairobi. Although the Ministry of Education selected the schools based on criteria that characterize most secondary schools in the country (level, sex composition, institutional arrangement, socio-economic setting, and geographical location), the experiences may not be similar to those of rural schools.

- Limitations associated with the data collection and analysis techniques: One limitation of self-administered interviews is that there is no opportunity to clarify unclear terms and to probe for additional information or detail. This leads to high rates of missing responses for questions the respondents do not clearly understand or feel they are not comfortable with. In addition, positive changes observed among students who read the communications materials compared to those who did not obtain or read them could be due to differences in characteristics between the two groups. The analysis technique used did not determine if the positive changes among those who read the materials still hold after controlling for such differences. 


\section{Conclusion and recommendations}

In conclusion, the pilot study showed that:

- in-school youth need accurate information not only on HIV and AIDS but other SRH issues as well;

- using comic books, role models and edutainment to communicate HIV and AIDS messages to in-school youth is acceptable to members of the school community; and

- the use of such channels leads to improved knowledge of SRH issues, enhanced communication about SRH, and positive changes in attitudes and behavior of students.

The major recommendations from the study are that:

- there is need to constantly provide HIV and AIDS and other SRH information to in-school youth using age-appropriate channels; and

- all education stakeholders (education managers, school principals, teachers, parents/guardians, and students) need to be involved in the conceptualization and design of such channels to ensure that they are acceptable and feasible within the school setting. 


\section{References}

Birungi, Harriet, John Frank Mugisha, Juliana Nyombi, Francis Obare, Humphres Evelia, and Hannington Nyinkavu. 2008. "Sexual and reproductive health needs of adolescents perinatally infected with HIV in Uganda." FRONTIERS Final Report. Washington, DC: Population Council.

Daily Nation. 2010. Ministry of Education National Special Needs Education (SNE) Policy Launched. Nairobi: Nation Media Group Limited, Thursday March 11, pp. 53-54.

Kelly MJ. 2003. The Development of HIV/AIDS Policies in the Education Sector in Africa. DPMN Bulletin: Volume X, Number 1.

Global Network of People Living with HIV/AIDS (GNP+) and the Joint United Nations Programme on HIV/AIDS (UNAIDS). 2009. Positive Health, Dignity and Prevention: Technical Consultation Report. Amsterdam: GNP+ and UNAIDS.

International Labour Organization (ILO) and United Nations Educational, Scientific and Cultural Organization (UNESCO). 2006. An HIV and AIDS workplace policy for the education sector in Southern Africa. Geneva: ILO and UNESCO.

Kenya National Bureau of Statistics (KNBS) [Kenya] and ICF Macro. 2010. Kenya Demographic and Health Survey 2008-09. Calverton, Maryland: KNBS and ICF Macro.

Ministry of Education and Sports [Uganda]. 2006. Education and Sports Sector Policy Guidelines on HIV and AIDS. Kampala: Ministry of Education and Sports.

Ministry of Education [Kenya]. 2004. Education Sector Policy on HIV and AIDS. Nairobi: Ministry of Education.

National AIDS and STI Control Programme [Ministry of Public Health and Sanitation, Kenya]. 2008. Guidelines for HIV Testing and Counselling in Kenya. Nairobi: NASCOP.

Obare, Francis, Harriet Birungi, Anne Katahoire, Hannington Nkayivu, and Aggrey David Kibenge. 2009. Special needs of in-school HIV positive young people in Uganda. New York and Nairobi: Population Council, Reproductive Health Program.

United Nations Educational, Scientific and Cultural Organization (UNESCO). 2006. EDUCAIDS: Towards a comprehensive education sector response: a framework for action. Paris: UNESCO.

Ward, Vivienne and John Mendelsohn. 2009. Supporting the educational needs of HIV-positive learners in Namibia. Paris: UNESCO. 
For more information, contact:

\author{
Project Director \\ APHIA II OR Project in Kenya \\ Population Council \\ General Accident Insurance House \\ Ralph Bunche Road \\ P.O. Box 1764300500 \\ Nairobi, Kenya
}

Tel: 254202713480 - 3

Fax: 254202713479

www.popcouncil.org/projects/239_APHIAll.asp

(P Population Council 